\title{
Feeding ecology of portunid crab, Carcinus aestuarii Nardo, 1847 in Çardak Lagoon (The Turkish Straits System)
}

\section{Çardak Lagünü (Türk Boğazlar Sistemi)'nde bulunan portunid yengeç, Carcinus aestuarii Nardo,1847'nin beslenme ekolojisi}

\author{
Seçil Acar ${ }^{1 *}$ • A. Suat Ateş ${ }^{2}$ \\ ${ }^{1}$ Çanakkale Onsekiz Mart University Faculty of Marine Sciences and Technology 17100 Çanakkale, Turkey \\ 2 Çanakkale Onsekiz Mart University Faculty of Marine Sciences and Technology 17100 Çanakkale, Turkey \\ https://orcid.org/0000-0002-6426-8095 \\ (D) https://orcid.org/0000-0002-4682-1926
}

Acar, S. \& Ateş, A.S. (2021). Feeding ecology of portunid crab, Carcinus aestuarii Nardo, 1847 in Çardak Lagoon (The Turkish Straits System) Ege Journal of Fisheries and Aquatic Sciences, 38(2), 155-159. DOI:10.12714/egejfas.38.2.03

Abstract: The aim of the present study was to determine the feeding ecology of portunid crab, Carcinus aestuarii in Çardak Lagoon. For this purpose, a total of 533 crab stomachs were analyzed. Stomach contents were examined under a binocular stereomicroscope and 240 (45\%) of the stomach samples were recorded as full (containing at least one food item) and 293 (55\%) were recorded as empty. The occupancy rates were $25 \%$ in 127 stomachs, $50 \%$ in 69 , and $100 \%$ of 44 . The main diet of crab individuals was composed of fragments of fish species. Diatoms were the least consumed food by crabs. A total of 8494 diet fragments were found in the stomachs. Total stomach content was $26.39 \mathrm{~g}$ of fish vertebrates having the highest weight $(3.58 \mathrm{~g})$.

Keywords: Carcinus aestuarii, diet, lagoon ecosystem, Turkish Straits System

Öz: Bu çalışmanın amacı Çardak Lagünü'ndeki portunid yengeç Carcinus aestuariỉnin beslenme ekolojisini belirlemektir. Bu amaçla toplam 533 yengeç midesi analiz edilmiştir. Mide içerikleri binoküler mikroskop altında incelenmiş ve $240(\% 45)$ mide örneği dolu (en az bir besin maddesi içeren) ve $293^{\prime}$ 'ü (\%55) boş olarak kaydedilmiştir. Doluluk oranları 127 midede $\% 25,69$ 'unda $\% 50$ ve 44 'ünde $\% 100$ 'dür. Yengeç bireylerinin ana besin maddesini balık türlerinin parçaları oluşturmuştur. Diatomlar yengeçler tarafından en az tüketilen besindir. Midede toplamda 8494 besin parçası bulunmuştur. Balık omurları en yüksek ağırlığa $(3.58 \mathrm{~g})$ sahip olarak toplam mide içeriği 26.39 g'dır.

Anahtar kelimeler: Carcinus aestuarii, diyet, lagün ekosistemi, Türk Boğazlar Sistemi

\section{INTRODUCTION}

Portunid crab, Carcinus aestuarii lives in estuaries and lagoon areas of the Mediterranean Ecosystem. Populations of Carcinus aestuarii can tolerate various environmental conditions (Abelló et al., 1997; Aydin, 2013). Carcinus aestuarii has both an omnivore and predator character with a high survival rate. C. aestuarii's diets depend on local species in the tidal zones (Yamada and Hauck, 2001). These local species interact with benthos and may have a negative impact on the environment where they live.

Crustaceans are known to be important representatives of the trophic chain in many marine ecosystems. Thus, C. aestuarii is the main diet for commercial fish such as eel, sea bass, and sea bream in lagoon systems. They also migrate between the lagoons on the Mediterranean coast to feed. $C$. aestuarii is one of the potential species known as a biological indicator which can easily adapt to estuarine and lagoon areas (Mori et al., 1990). Additionally, it is the most common species of decapod crustaceans in the tidal zone, spreading from the shallow coastal zone to a depth of $60 \mathrm{~m}$. This species is recorded in the estuaries and zones with low salinity as well (Lyons et al., 2012). Crab species include filter feeders, sand cleansers, mud, plant, and carrion feeders, predators, commensals, and parasites (Dall and Moriarty, 1983). Thus, stomach content analysis provides the most accurate information about the general diets of these species (Williams, 1981). Population dynamics and several biological variables of $C$. aestuarii were recently described from the coastal lagoons in Turkey (Can et al., 2004; Özcan et al., 2009; Koçak et al., 2011; Özbek et al., 2012), Tunisia (Baklouti et al., 2013), and Italy (Mori et al., 1990; Matozzo et al., 2011; Lumare et al., 2009; Cilenti et al., 2014), in Mediterranean ecosystems. C. aestuarii tolerating a wide range of physico-chemical variables is thought to be especially effective on benthic communities with their nutritional preferences. Therefore, the purpose of this study was to understand the feeding ecology of $C$. aestuarii in the Çardak Lagoon.

\section{MATERIAL AND METHODS}

The study was carried out in Çardak Lagoon which is a part of the Turkish Straits System. Samplings were carried out monthly between April 2015 and March 2016 by means of a static traditional trap used for the eel fishery. The traps were deployed during a 48-h period between the depths of 1.5 and $2 \mathrm{~m}$ from 6 different points in Çardak Lagoon (Figure 1). 


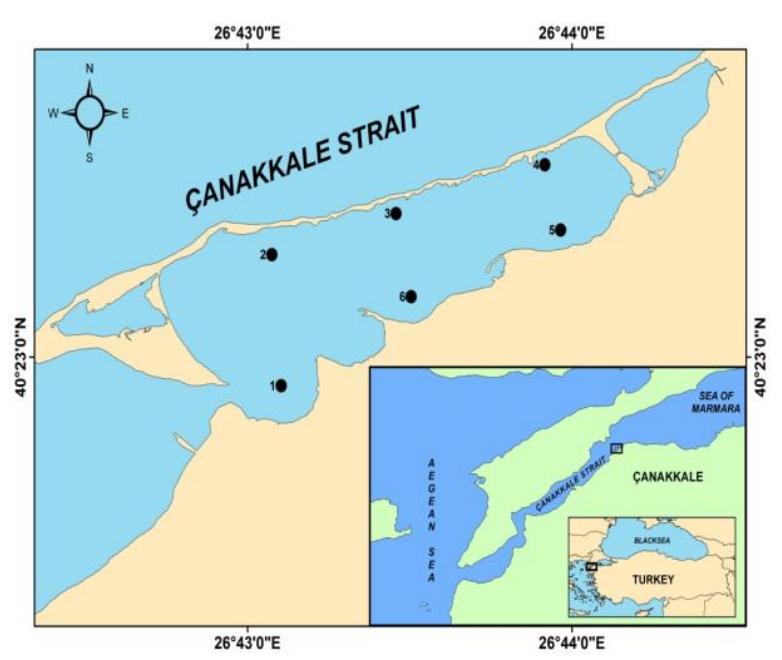

Figure 1. The map of the study area

After the crab samples were transferred to the laboratory, crab specimens were dissected and their stomachs were separated. The weights of the stomachs were measured on a precision scale of $\pm 0.001 \mathrm{gr}$ and then stored in Eppendorf tubes containing $70 \%$ ethanol. Stomach contents were examined under an OLYMPUS Brand SZX7 Model binocular stereomicroscope. Gastric occupancy rates were divided into 4 groups and were classified as empty (0\%), low-filled (25\%), half-filled $(50 \%)$, and full-filled $(100 \%)$. Relative abundance $(\mathrm{F} \%)$, frequency of occurrence $(\mathrm{N} \%)$, volumetric occupancy (V\%) and IRI (Index of Relative Importance) values and vacuity index (Vacuity Index, VI) were also calculated. Chisquare (X2) test was used to analyze the changes in Vacuity index by months. SIMPER and ANOSIM analysis were performed to determine the diet differences by month and sex. Statistical analysis were carried out using PAST 4.03.

$\mid \mathrm{RI}=(\mathrm{N}+\mathrm{V})^{*} \mathrm{~F}$;

$\mathrm{VI}=$ Total of Empty stomach ${ }^{*} 100 /$ Total number of stomach

\section{RESULTS}

A total of 553 individuals were found in the study area between April 2015 and March 2016. The average length of carapace in crabs ranged between $23.36-73.61 \mathrm{~mm}$. While the minimum carapace length in females was $23.36 \mathrm{~mm}$, the maximum was $56.29 \mathrm{~mm}$. In male crabs, the minimum carapace length was $26.2 \mathrm{~mm}$ and the maximum length was $73.61 \mathrm{~mm}$ (Figure 2). A total of 195 stomachs (115 empty and 80 full) in females and 338 stomachs in males were evaluated.

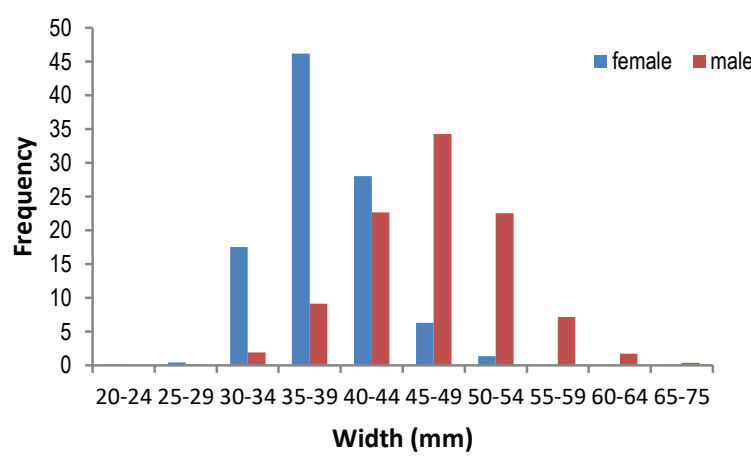

Figure 2. Proportional (\%) distributions of phytoplankton groups in abundance basis according to seasons

Of the analyzed stomachs, 179 were empty and 159 were completely full. No diet fragments were found in 293 of the stomachs examined. The occupancy rates were $25 \%, 50 \%$ and $100 \%$ in 127, 69 and 44 of the crab stomachs, respectively. Main diet of the crab individuals was composed of fish fragments while the diatoms were the least consumed. A total of 8494 diet fragments were counted in all stomachs. Total weight of the stomach content was $26.39 \mathrm{~g}$ and $3.58 \mathrm{~g}$ of the total weight was composed of fish vertebrates. Additionally, fish vertebrates were observed in 171 of the stomachs. Besides the fish vertebrates, detritus was also a common food group with a total weight of $3.45 \mathrm{~g}$ in the stomach content (Table 1; Figure 3).

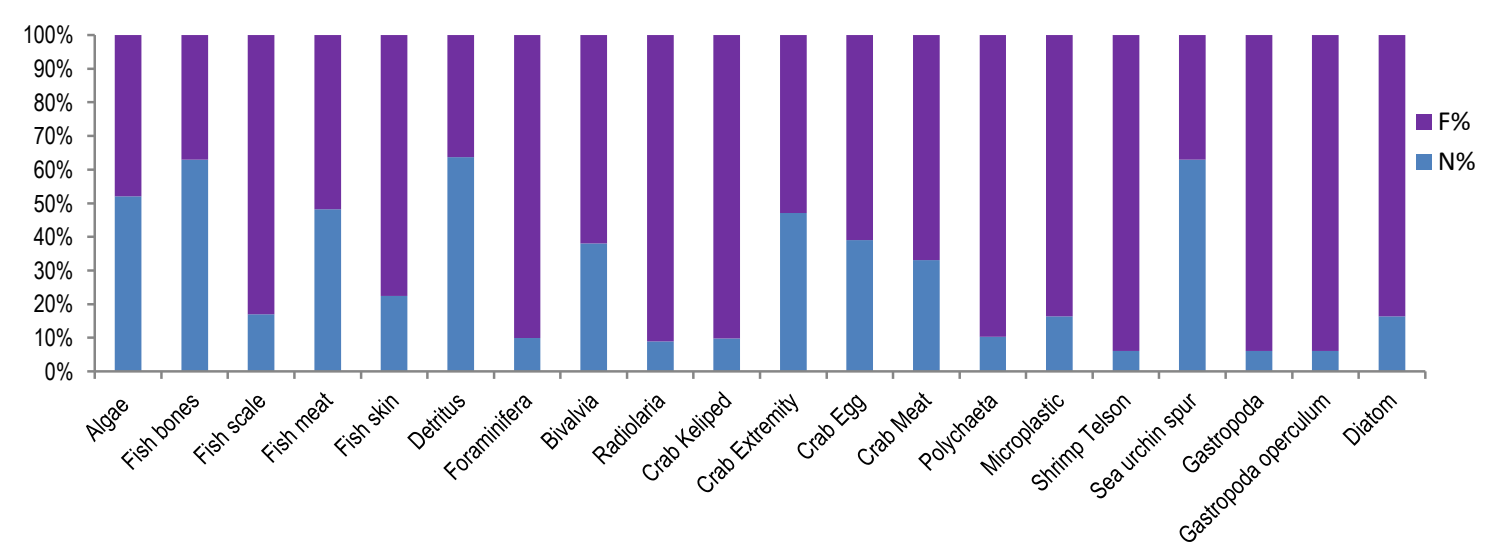

Figure 3. $\mathrm{N} \%$ and $\mathrm{F} \%$ values of stomach content 
Table 1. Stomach content of $C$. aestuarii (N\%, F\% and IRI values)

\begin{tabular}{llllll}
\hline Feeding Type & & & & & \\
Diet fragments & N\% & F\% & V\% & IRI & IRI\% \\
\hline Photophilic algae & 11.91 & 10.99 & 3.36 & 167.90 & 5.94 \\
Fish bones & 52.35 & 30.81 & 9.63 & 1909.72 & 67.60 \\
Fish scale & 3.04 & 14.77 & 7.13 & 150.17 & 5.32 \\
Fish meat & 16.25 & 17.48 & 8.74 & 436.71 & 15.46 \\
Fish skin & 0.62 & 2.16 & 4.30 & 10.65 & 0.38 \\
Detritus & 6.65 & 3.78 & 9.28 & 60.27 & 2.13 \\
Foraminifera & 0.26 & 2.34 & 1.21 & 3.44 & 0.12 \\
Bivalvia & 3.21 & 5.23 & 4.98 & 42.79 & 1.51 \\
Radiolaria & 0.11 & 1.08 & 0.54 & 0.70 & 0.02 \\
Crab cheliped & 0.29 & 2.70 & 6.05 & 17.15 & 0.61 \\
Crab extremities & 1.28 & 1.44 & 4.98 & 9.02 & 0.32 \\
Crab egg & 0.58 & 0.90 & 1.56 & 1.92 & 0.07 \\
Crab meat & 0.62 & 1.26 & 1.75 & 2.99 & 0.11 \\
Polychaetes & 0.08 & 0.72 & 0.40 & 0.35 & 0.01 \\
Microplastic & 0.11 & 0.54 & 0.97 & 0.58 & 0.02 \\
Shrimp telson & 0.04 & 0.54 & 0.67 & 0.38 & 0.01 \\
Sea urchin spur & 2.45 & 1.44 & 4.20 & 9.58 & 0.34 \\
Gastropod & 0.05 & 0.72 & 0.65 & 0.50 & 0.02 \\
Gastropod operculum & 0.06 & 0.90 & 0.27 & 0.30 & 0.01 \\
Diatom & 0.04 & 0.18 & 0.32 & 0.06 & 0,00 \\
\hline N\%: N & & &
\end{tabular}

$\mathrm{N} \%$ : Numerical percentage of food types, F\%: Frequency percentage, V\%: Weight percentage, IRI: Index of relative importance

The relationships between diets and amounts of diet by months were analyzed by t-test. The difference between the diet levels by months was statistically significant $(p=0.000$; $\mathrm{p}<0.05)$. Although main diets for both males and females were the fish meat and the vertebrates, fragments of photophilic algae were also found as important food sources.
Generally being more aggressive cannibalism was observed in females as well. For example, eggs of other female individuals were found in the stomachs of several female individuals. The relationship between male and female diets was analyzed by a chi-square test and the relationship was found to be statistically significant $(p=0.002 ; p<0.05)$ (Table 2$)$

Table 2. Values of diversity index belonging to stomach content by months

\begin{tabular}{|c|c|c|c|c|c|c|c|c|c|c|c|c|}
\hline & April & May & June & July & August & September & October & November & December & January & February & March \\
\hline Number of content types & 7 & 7 & 8 & 7 & 4 & 7 & 4 & 9 & 10 & 10 & 17 & 17 \\
\hline Number of content & 200 & 526 & 459 & 178 & 99 & 250 & 513 & 901 & 1300 & 1301 & 976 & 1791 \\
\hline Dominance (d) & 0.29 & 0.389 & 0.465 & 0.547 & 0.636 & 0.338 & 0.421 & 0.259 & 0.302 & 0.354 & 0.271 & 0.405 \\
\hline Shannon_H' & 1.465 & 1.137 & 1.022 & 0.952 & 0.745 & 1.387 & 0.954 & 1.488 & 1.549 & 1.393 & 1.773 & 1.443 \\
\hline Eveness & 0.618 & 0.445 & 0.347 & 0.37 & 0.526 & 0.571 & 0.649 & 0.492 & 0.47 & 0.402 & 0.346 & 0.248 \\
\hline
\end{tabular}

While the highest value $\left(\mathrm{H}^{\prime}=1.77\right)$ of diet diversity index was recorded in February and November $\left(H^{\prime}=1.48\right)$ the lowest diet index value $\left(\mathrm{H}^{\prime}=0.95\right)$ was recorded in August. The highest amount of diet (number of individuals $=1791$ ) was found in March. Shannon-weaver index showed that variety and amount of diet were higher in females than in males $\left(H^{\prime}=1.69\right)$ (Table 3).

ANOSIM analysis was used to determine the difference of feeding activity by months. The result of ANOSIM analysis showed that the type of the diet was important in different months $(R=0.148 ; p<0.05)$. The most important contribution to diet depending on the prey groups were found to be fish vertebrates $(43.18 \%)$ and fragments of photophilic algae $(15.67 \%)$. Additionally, fish meat, detritus, and mussel fragments were the groups that contribute to diets the most.
When the average abundances were examined according to the months, depending on the ratio of the fish vertebrate the highest values were observed in July $(71.9 \%)$ and August $(78.8 \%)$. Changes in IRI (\%) values by months were calculated with Spearman Rank Correlation (rs). The relationship between \% IRI values by month ( $r$ s $=0.214 ; p$ $<0.05$ ) was found to be statistically significant.

Fish vertebrates and fragments in crab stomachs were observed throughout the year. The highest consumed fragments of photophilic algae fragments were also found all through the year except the gastric samples obtained in August. Fragments of sea urchins were found mostly in stomach samples belonging to March, February and November (Figure 4). 
Table 3. Values of diversity index belonging to stomach content by sex

\begin{tabular}{lll}
\hline & Female () & Male (ぷ) \\
\hline Number of content types & 17 & 20 \\
Number of content & 2195 & 6299 \\
Dominance & 0.287 & 0.335 \\
Shannon_H' & 1.696 & 1.54 \\
Eveness & 0.32 & 0.233 \\
Margalef & 2.08 & 2.17 \\
\hline
\end{tabular}

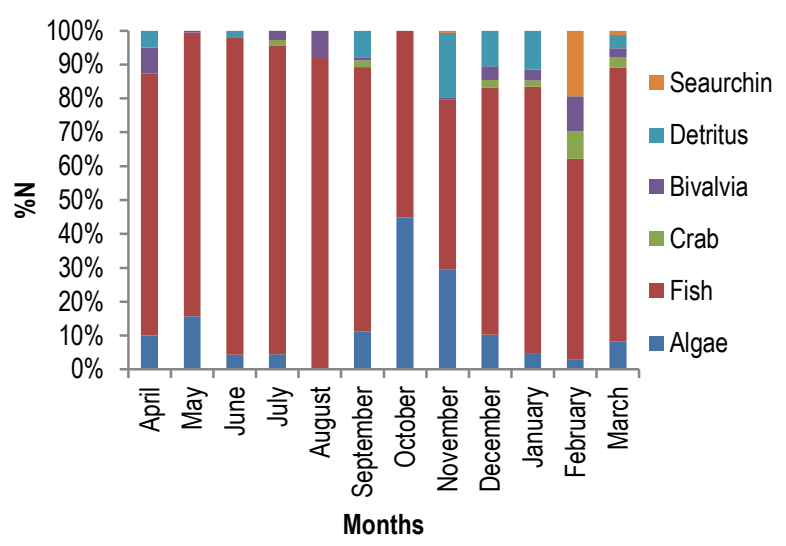

Figure 4. Diets in the stomachs of $C$. aestuarii specimens

\section{DISCUSSION}

Having information about the diets of a species in nature is very important in terms of understanding its feeding preferences and the relationships between the animal groups (Josileen, 2011). Although decapod crustaceans feed on macroscopic organisms, identification of the various food items as well as a reliable estimate of their (relative) quantity, are both very difficult (Josileen, 2011). The crabs use their mouthparts to cut the food into small pieces and then the gastric mill ossicles further reduce the food to unidentifiable fragments. Most researchers use the foregut contents to study the quantity and nature of the different diets consumed by crab species (Sukumaran and Neelakandan, 1997; Williams, 1981; Chande and Mgaya, 2003, 2004; Josileen, 2011). Adults of $C$. aestuarii individuals have an omnivorepredator feeding type, however, they are aggressively competitive. Crab species prefer mostly annelids, gastropods, mussels, fishes, photophilic algae and other crustaceans (e.i. shrimp, crab). Also, the cannibalism observed in this species is very important (Leignel et al., 2014). In this study, it was concluded that the behavior of cannibalism is high, especially in female individuals. For example, it has been determined in the stomach content that females consume crab eggs and limbs. On the other hand, one of the most important food sources of crab individuals is mussels. Mussel species along with their diets also vary according to the endemic/local species in the area where they live (Yamada and Hauck, 2001, Chen et al., 2004; Tepolt and Somero, 2014; Aydin, 2013). Baeta et al. (2006), studied the diet ecology of C. maenas in Mondego estuarine area (Portuguese coast).
According to Baeta et al. (2006) shrimp, polychaete, and fish species are the most important diets of $C$. maenas. Recently, Chaves et al. (2010) analyzed, the feeding pattern of $C$. maenas in the same area and stated that $C$. maenas prefers predominantly the bivalves, polychaeta and photophilic algae fragments. Diet ecology of the Japanese population of the Mediterranean endemic $C$. aestuarii was also addressed by Chen et al. (2004). Chen et al. (2004) stated that individuals of $C$. aestuarii consumed 87 various fragments of peracarid and eucarid crustaceans (including cirriped, amphipod, decapod) and mostly bivalve species. Chen et al. (2004) indicated that Mediterranean mussel, Mytilus galloprovincialis, has been identified as a species commonly consumed by individuals of $C$. aestuarii $(66.4 \%)$. Percentage of vegetative material in $C$. aestuarii stomachs is very low $(1.9 \%)$ and both sex have no significant effect on diets $(p=0.56 ; p>0.05)$. Yet, $C$. aestuarii was previously reported to be opportunistic and omnivorous (Chen et al., 2004). In Çardak Lagoon, the diets preferred by crabs were mostly fish species such as sea bream and goby species $(I R I(\%)=52.35)$. Diatom and shrimp fragments were rarely observed in the stomach contents of crabs $(I R I(\%)=0.04)$. Sex difference seemed to be effective on the crabs' diets in the study area ( $p=0.002 ; p<0.05)$. Additionally, crab specimens in the lagoon area showed similar feeding strategy as omnivorous or opportunistic type.

Changes in the diets of $C$. aestuarii with respect to months and localities were also associated with availability of food sources. As indicated in previous studies, crabs pursued different hunting strategies throughout the year and this behavior was realized for energy expenditure, growth and reproduction as well as for regeneration of shell with $\mathrm{CaCO}_{3}$ (Rosas et al., 1994; Mantelatto and Fransozo, 1999; Jewett and Feder, 1982; Feder and Keiser, 1980; Chen et al, 2004). Therefore, mussels and crustaceans in shallow water have created an important part of the dietary component throughout the year since they contain abundant sources of $\mathrm{CaCO}_{3}$.

Being opportunistic omnivores, Portunidae crabs rarely include motile forms such as fish and shrimp species in their diets (Ropes, 1968; Patel et al., 1979; Williams, 1982; Le Roux et al., 1990). In addition, it is known that omnivore feeding style minimizes the dependence of the animal on a specific type of food source and increases the variety of feeding (Chen et al., 2004). Although, C. aestuarii individuals also have a largely opportunistic omnivore diet as with other Portunidae crabs, they are more selective about their food preferences. In the present study conducted in Çardak Lagoon, it has been observed that the nutritional preferences of crabs were largely omnivorous alongside with mobile species such as fish. Thus, it can be concluded that especially with this type of diet, a negative effect on benthic fauna and flora can be expected. In addition, this study supported other studies conducted on nutrition ecology in similar aquatic systems.

\section{ACKNOWLEDGEMENTS}

This research was supported by Çanakkale Onsekiz Mart University Scientific Foundation, of Project Code 2015/406 


\section{REFERENCES}

Abelló, P., Aagaard, A., Warman, C.G. \& Depledge, M.H. (1997). Spatial variability in the population structure of the shore crab Carcinus maenas (Crustacea, Brachyura) in shallow water tidal fjord. Marine Ecology Progress Series, 147, 97-103 DOI:10.3354/meps147097

Aydin, M. (2013). Length-Weight relationship and reproductive features of the Mediterranean Green Crab, Carcinus aestuarii Nardo, 1847 (Decapoda: Brachyura) in the Eastern Black Sea, Turkey. Pakistan Journal of Zoology, 45(6), 1615-1622. DOI: 0030-9923/2013/0006-1615

Baeta, A., Cabral, H.N., Marques, J.C. \& Pardal, M.A. (2006). Feeding ecology of the green crab, Carcinus maenas (L., 1758) in a temperate estuary, Portugal. Crustaceana, 79(10), 1181-1193. DOI:10.1163/156854006778859506

Baklouti, S., Derbali, A., Dhieb, K. \& Jarboui, O. (2013). Reproductive biology of the Mediterranean green crab, Carcinus aestuarii Nardo, 1847 (Crustacea: Portunidae), in the Gulf of Gabes (Tunisia, Central Mediterranean). Cahiers de Biologie Marine, 54, 411-417 DOI:10.21411/CBM.A.2E5C5488

Can E., Tıraşın, E.M. \& Cihangir, B. (2004). Çakalburnu Dalyanı'nda Carcinus aestuarii, (Nardo, 1847) türü üzerine gözlemler. Türk Sucul Yaşam Dergisi, 2(3), 77-84

Chande, A.I. \& Mgaya, Y.D. (2003). The fishery of Portunus pelagicus and the species diversity of portunid crabs along the coast of Dar es Salaam. Western Indian Ocean Journal of Marine Science, 2, 75-84. DOl:10.4314/wiojms.v2i1.28431

Chande, A.I. \& Mgaya, Y.D. (2004). Food habits of the blue swimming crab Portunus pelagicus along the Coast of Dar es Salaam, Tanzania. Western Indian Ocean Journal of Marine Science, 3,37-42.

Chaves, M.L., Horta, M.S., Chainho, P., Costa, M.J. \& Costa, J.L. (2010). New additions to the feeding ecology of Carcinus maenas (L., 1758) in a South-western Europe estuary (Portugal). Cahiers de Biology Marine, 51, 229-238 DOI: 10.21411/CBM.A.86A0CE1C

Chen, R.B., Watanabe, S. \& Yokota, M. (2004). Feeding habits of an exotic species, the Mediterranean green crab Carcinus aestuarii, in Tokyo Bay. Fisheries Science, 70, 430-435 DOI: 10.1111/j.1444-2906.2004.00822.x

Cilenti, L., D’Errico, G., Scirocco, T., Manzo, C. \& Fabbrocini, A. (2014). Spatial variability in the population structure of the Carcinus aestuarii in Varano lagoon. Transitional Waters Bulletin, 8 (1), 24-31. DOI: 10.1285/i1825229Xv8n1p24

Dall, W. \& Moriarty, D.J.W. (1983). Functional aspects of nutrition and digestion. In: Bliss D.E. \& Mantel L.H. (eds.), The biology of Crustacea, 5, Internal anatomy and physiological regulation: 255-261. (Academic Press, New York). DOI: 10.1016/B978-0-12-106405-1.50015-1

Feder, H. M., \& Keiser, G. E. (1980). Intertidal biology. Port Valdez, Alaska: Environmental Studies 1976-1979, Chapter 8. Occasional Publication, (5), 1-373.

Jewett, S.C. \& Feder, H.M. (1982). Food and feeding habits of the King Crab Paralithodes camtschatica near Kodiak Island. Alaska Marine Biology, 66, 243-250. DOI: 10.1007/BF00397029

Josileen, J. (2011). Food and feeding of the blue swimmer crab, Portunus pelagicus (Linnaeus, 1758) (Decapoda, Brachyura) along the coast of mandapam, Tamil Nadu, India. Crustaceana, 84(10), 1169-1180. DOI:10.1163/001121611X590111

Koçak, C., Acarlı, D., Katağan, T. \& Özbek, M. (2011). Morphometric characters of the Mediterranean green crab (Carcinus aestuarii Nardo, 1847) (Decapoda, Brachyura), in Homa Lagoon, Turkey. Turkish Journal of Zoology, 35 (4), 551-557 DOl:10.3906/zoo-0903-5

Leignel, V., Stilmann, J.H., Baringou, S., Thabet, R. \& Metais, I. (2014). Overview on the European green crab Carcinus spp. (Portunidae, Decapoda), one of the most famous marine invaders and ecotoxicological models. Environmental Science Pollution Research, 21, 4929-9144. DOI: 10.1007/s11356-014-2979-4
Le Roux, P.J., Branch G.M. \& Joska M.A.P. (1990). On the distribution, diet and possible impact of the invasive European shore crab Carcinus maenas (L.) along the South African Coast. South African Journal of Marine Science, 9, 85-93 DOI:10.2989/025776190784378835

Lumare, L., Lumare, D., Florio, M., Scirocco, T. \& Lumare F. (2009). I crostacei decapodi del lago di acquatina: struttura delle popolazioni e ciclo riproduttivo. Thalassia Salentina, 31, 83- 102. DOI:10.1285/i15910725v31supp83

Lyons, L.J., O'riordan, R.M., Cross, T.F. \& Culloty, S.C. (2012). Reproductive biology of the shore crab Carcinus maenas (Decapoda, Portunidae): a macroscopic and histological view. Invertebrate Reproduction \& Development, 56 (2), 144-156. DOI:10.1080/07924259.2011.582693

Mantelatto, F.L.M. \& Fransozo, A. (1999). Reproductive biology and moulting cycle of the crab Callinectes ornatus (Decapoda, Portunidae) from the Ubatuba region, Sao Paulo, Brazil. Crustaceana, 72, 63-76. DOI:10.1163/156854099502871

Matozzo, V., Gallo, C. \& Marin, M.G. (2011). Can starvation influence cellular and biochemical parameters to the crab Carcinus aestuarii? Marine Environmental Research, 71, 207-212.

DOI:10.1016/j.marenvres.2011.01.004

Mori, M., Mancon, R. \& Fanciulli, G. (1990). Notes on the reproductive biology of Carcinus aestuarii Nardo (Crustacea, Decapoda) from the lagoon of San Teodoro (Island of Sardinia, Italy). Rivista di Idrobiologia, 29, 763-774.

Özbek, M., Koçak, C. \& Acarlı, D. (2012). Reproductive biology of the Mediterranean Green Crab Carcinus aestuarii Nardo, 1847 (Crustacea, Brachyura, Portunidae) in Homa Lagoon, Aegean Sea, Turkey. Oceanological and Hydrobiological Studies, 41(4), 77-80 DOI:10.2478/s13545-012-0041-z

Özcan,T., Bakır, K. \& Katağan, T. (2009). Length/width-weight relationships of the Mediterranean green crab Carcinus aestuarii Nardo, 1847 in the Homa Lagoon, Aegean Sea Turkey. Journal of Fisheries Science.com, 3, 1-4. DOI: $10.3153 /$ fscom. 2009001

Patel, N.M., Chhaya, N.D. \& Bhaskaran, M. (1979). Stomach contents of Portunus pelagicus (Linn.) from $A D$ net catches. Indian Journal of Marine Science, 8, 48-49.

Ropes, J.W. (1968). The feeding habits of the green crab Carcinus maenas. Fisheries Bulletin, 67, 183-203.

Rosas, C., Lazaro-Chaves, E. \& Buckle-Ramirez, F. (1994). Feeding habits and food niche segregation of Callinectes sapidus, C. rathbunae, and C. similis in a subtropical coastal lagoon of the Gulf of Mexico. Journal of Crustacean Biology, 14, 371-382 DOI:10.2307/1548915

Sukumaran, K.K. \& Neelakantan, B. (1997). Food and feeding of Portunus (Portunus) sanguinolentus (Herbst) and Portunus (Portunus) pelagicus (Linnaeus) (Brachyura: Portunidae) along the Karnataka coast. Indian Journal of Marine Science, 26(1), 35-38.

Tepolt, C.K. \& Somero, G.N. (2014). Master of all trades: thermal acclimation and adaptation of cardiac function in a broadly distributed marine invasive species, the European green crab, Carcinus maenas. Journal of Experimental Biology, 217, 1129-1138 DOI:10.1242/jeb.093849

Williams, M.J. (1981). Methods for analysis of natural diet in portunid crabs (Crustacea: Decapoda: Portunidae). Journal of Experimental Marine Biology and Ecology, 52, 103-113. DOI: 10.1016/0022-0981(81)90174-X

Williams, M.J. (1982). Natural food and feeding in the commercial sand crab Portunus pelagicus Linnaeus, 1766 (Crustacea: Decapoda: Portunidae) in the Moreton Bay, Queensland. Journal of Experimental Marine Biology and Ecology, 59, 165-176. DOI: 10.1016/0022-0981(82)90113-7

Yamada, S.B. \& Hauck, L. (2001). Field identification of the European green crab species. Carcinus maenas and Carcinus aestuarii Journal of Shellfish Research, 20(3), 905-912. 